\title{
AKTIVITAS IMUNOGLOBULIN M (IgM) EKSTRAK BUAH MENGKUDU (Morinda citrifolia L.) TERHADAP TIKUS PUTIH (Rattus Norvegiens)
}

\author{
Ilham Firdaus Rizky Perkasa*, Victoria Yulita Fitriani, Arsyik Ibrahim \\ Laboratorium Farmakologi dan Toksikologi, Fakultas Farmasi, Universitas Mulawarman, Samarinda, \\ Kalimantan Timur \\ *Corresponding author email:ilhamfirdaus14@aol.com
}

\begin{abstract}
Pathogenic microorganisms in the environment that causes the disease. Where is the body's immune system require the presence of inadequate intake to boost the immune system. The great morinda contains of xeronine and peroxine compound which is able to stabilize the damaged cell function. This research aims to recognize the major role of the great morinda extract in increasing immunoglobulin $M$ (IgM) activity and best doses of the great morinda extract in increasing immunoglobulin M (IgM) activity towards albino rat. The research's using experiment method through hemagglutination test. The doses used for the extract are $100 \mathrm{mg} / 200 \mathrm{gBB}$, $200 \mathrm{mg} / 200 \mathrm{gBB}$, and $300 \mathrm{mg} / 200 \mathrm{gBB}$ and stimuno doses $0,9 \mathrm{mg} / 200 \mathrm{gBB}$ as a positive control. The research data further processed by using variant analisis (Anava). Anova statistical results obtained doses extract of great morinda is not significant and best dose used for the t-test of two independent samples results $300 \mathrm{mg} / 200 \mathrm{gBB}$ dose had better activity than the dose $100 \mathrm{mg} / 200 \mathrm{gBB}, 200 \mathrm{mg} / 200 \mathrm{gBB}$ and negative controls. The research results the extract of great morinda could increase the activity of immunoglobulin $M(\operatorname{IgM})$ the best doses will be $300 \mathrm{mg} / 200 \mathrm{gBB}$.
\end{abstract}

Keyword : The Great Morinda Extract, Morinda citrofolia L., Activity of Immunoglobulin G, Immunomodulator, Immuno Deficiency

\begin{abstract}
ABSTRAK
Mikroorganisme patogen terdapat di lingkungan yang menyebabkan penyakit. Dimana sistem imun tubuh yang tidak memadai memerlukan adanya asupan untuk meningkatkan sistem imun. Buah mengkudu mengandung senyawa xeronine dan proxeronine yang mampu menormalkan fungsi sel yang rusak Penelitian ini bertujuan untuk mengetahui apakah ekstrak buah mengkudu dapat meningkatkan aktivitas imunoglobulin M (IgM) dan berapa dosis terbaik ekstrak buah mengkudu yang dapat menigkatkan aktivitas immunoglobulin $M$ pada tikus putih. Penelitian dengan metode eksperimen yaitu dengan menggunakan metode Hemaglutinasi Tes. Dosis yang digunakan untuk ekstrak adalah $100 \mathrm{mg} / 200 \mathrm{gBB}$, 200mg $/ 200 \mathrm{gBB}, 300 \mathrm{mg} / 200 \mathrm{gBB}$ dan stimuno dosis $0,9 \mathrm{mg} / 200 \mathrm{gBB}$ sebagai kontrol positif. Data penelitian selanjutnya diolah dengan menggunakan analisis varian (Anava). Hasil statistik anava diperoleh dosis ekstrak buah mengkudu tidak signifikan dan untuk dosis terbaik digunakan uji-t dua sampel yang diperoleh hasil dosis $300 \mathrm{mg} / 200 \mathrm{gBB}$ mempunyai aktivitas yang lebih baik daripada dosis $100 \mathrm{mg} / 200 \mathrm{gBB}, 200 \mathrm{mg} / 200 \mathrm{gBB}$ dan kontrol negatif. Hasil peneltian yang dihasilkan adalah bahwa ekstrak buah mengkudu mampu meningkatkan aktifitas imunoglobulin $\mathrm{M}$ (IgM), dosis terbaik ekstrak buah mengkudu yang mampu meningkatkan aktivitas imunoglobulin $\mathrm{M}(\mathrm{IgM})$ adalah dosis $300 \mathrm{mg} / 200 \mathrm{gBB}$.
\end{abstract}

Kata Kunci : Ekstrak Buah Mengkudu, Morinda citrifolia L., Aktivitas Imunoglobulin G, Imunomodulator, Sistem Imun

Submitted on: 5 January $2017 \quad$ Accepted on: 15 February 2017

DOI: https://doi.org/10.25026/jsk.v1i6.69

Jurnal Sains dan Kesehatan. 2016. Vol 1. No 6. 


\section{PENDAHULUAN}

Banyak penyakit-penyakit yang disebabkan oleh terkenanya paparan mikroorganisme patogen seperti virus, bakteri dan jamur dimana mikroorganisme patogen ini terus berkembang dan berevolusi sehingga mikroorganisme patogen ini menjadi resisten terhadap obatobat yang telah ada (Subowo, 2009).

Pada keadaan normal tubuh dapat melawan paparan mikroorganisme patogen karena adanya sistem imun yang terdapat dalam tubuh, tetapi pada saat sistem imun berkurang atau tidak memadai paparan mikroorganisme patogen dapat menimbulkan berbagai penyakit. Sehingga perlu adanya upaya untuk mempertahankan sistem imun agar mampu berkerja maksimal dalam mempertahankan diri dari paparan mikroorganisme patogen. Salah satu upaya untuk mempertahankan sistem imun adalah dengan pemberian imunomodulator (Radji, 2010).

Imunomodulator zat-zat yang mempengaruhi reaksi biologis tubuh terhadap zat-zat asing. Fungsi sistem imun dapat distimulasi (imunostimulator) maupun di tekan (imunosupresiva). Imunostimulator secara tak langsung berkhasiat mereaktivasi sistem imun yang rendah dengan meningkatkan respon imun tak spesifik. Imunosupresiva adalah zat-zat yang justru menekan aktivitas sistem imun dengan jalan interaksi di berbagai titik dari sistem tersebut (Tan, 2003).

Zaman sekarang ini ada sebuah fenomena kembali ke alam dalam mengatasi masalah kesehatan, karena obatobat sintesis yang beredar di lingkungan masyarakat banyak menimbulkan efek samping yang tidak diinginkan. Salah satu tanaman obat yang berfungsi sebagai imunomodulator adalah mengkudu (Morinda citrifolia L.). Beberapa penelitian-penelitian ilmiah membuktikan bahwa jus mengkudu mampu meningkatkan fungsi kekebalan tubuh dan membantu memperbaiki kerusakan sel. Salah satu penelitian yang memperkuat pernyataan tersebut adalah laporan penelitian dari Hirazumi. Hirazumi pada tahun 1996 menyatakan bahwa jus buah mengkudu berfungsi sebagai imunomodulator yang mempunyai efek antikanker, tetapi penelitian-penelitian lebih lanjut sangat dibutuhkan untuk membuktikan penemuan tersebut (Suhirman, 2009). Dari beberapa pernyataan yang telah dikemukakan, maka dilakukan penelitian untuk mengetahui apalah ekstrak buah mengkudu mempunyai aktivitas dalam peningkatan immunoglobulin M (IgM) pada tikus putih.

\section{METODE PENELITIAN}

\section{Bahan}

Buah mengkudu (Morinda citrifolia L.) Buah mengkudu yang akan diteliti setengah matang berwarna hijau mengkilat dan daging buahnya masih keras; Pelarut etanol 70\%); Larutan PBS (Phosphate Buffered Saline) pH 7,2, Sel Darah Merah Kambing (SDMK) 1\%, aquades, dan stimuno.

\section{Alat}

Timbangan analitik (And gf 300), rotary evaporator (Buchi); Spoid oral; Spoid injeksi (Terumo); Sentrifuge (PLC Series); Seperangkat pelaratan kaca (Iwaki Pyrex); pH meter; Sentrifuse; penangas air; pipet mikro; Plat tetes, dan Inkubator. 


\section{Prosedur Penelitian}

\section{a. Perlakuan Terhadap Hewan Uji}

Tikus putih yang digunakan sebanyak 15 ekor yang telah dibagi menjadi lima kelompok, masing-masing kelompok terdiri dari 3 ekor tikus putih. Kelompok pertama sebagai kontrol negatif hanya diberikan imunisasi SDMK 1\% secara interperitonial. Kelompok kedua sampai keempat sebagai perlakuan pengujian yang diberi imunisasi SDMK $1 \%$ secara interperitorial pada hari pertama dan diberi ekstrak buah mengkudu (EBM) dengan variasi dosis yang berbeda yaitu pada kelompok kedua diberi dosis ekstrak buah mengkudu 100mg/200gBB, kelompok ketiga dosis ekstrak buah mengkudu 200mg/200gBB, kelompok keempat dosis ekstrak buah mengkudu $300 \mathrm{mg} / 200 \mathrm{gBB}$ diberi secara oral selama 1 minggu. Kelompok kelima sebagai kontrol positif diberi imunisasi SDMK 1\% secara interperitorial pada pertama dan diberi kontrol positif (stimuno) secara oral selama satu minggu. Setelah 1 minggu darah tikus diambil dan serum darah tersebut disimpan sampai dilakukan reaksi hemaglutinasi.

\section{b. Pengujian Hemaglutinasi}

Tabung yang berisi serum dipanaskan di atas penagas air yang bersuhu $56^{\circ} \mathrm{C}$ selama 30 menit (dekomplementasi), disiapkan sepuluh seri tabung uji. Dimasukan $100 \mu \mathrm{L}$ larutan PBS (Phosphate Buffered Saline) pada tabung kedua sampai sepuluh, sedangkan tabung pertama dibiarkan kosong. $200 \mu \mathrm{L}$ serum yang telah didekomplementasikan dimasukan ke dalam tabung pertama. Diambil $100 \mu \mathrm{L}$ dari kolom pertama kemudian memasukannya ke tabung kedua, homogenkan. Setelah itu ambil $100 \mu \mathrm{L}$ dari tabung kedua ke tabung yang ketiga lalu homogenkan, demikian seterusnya sampai tabung kesepuluh. Setelah pengenceran sampai seri yang terakhir buang $100 \mu \mathrm{L}$ serum pengenceran terakhir. Dengan demikian didapat 10 seri pengenceran serum dengan kelipatan dua yaitu $\frac{1}{2}$, $\frac{1}{4}, \frac{1}{8}, \frac{1}{16}, \frac{1}{32}, \frac{1}{64}, \frac{1}{128}, \frac{1}{258}, \frac{1}{512}, \frac{1}{1024}$.

Kemudian diinkubasi pada suhu $37^{\circ} \mathrm{C}$ selama 1 jam dan diamati hemaglutinasi secara visual. Pengamatan tersebut berdasarkan adanya penyebaran dan pengendapan SDMK pada dasar plat tetes yang terlihat jelas bila dari posisi atas tegak lurus terhadap dasar plat tetes.

\section{HASIL DAN PEMBAHASAN}

\section{a. Pendahuluan}

Pengujian aktivitas imunoglobulin M (IgM) ekstrak buah mengkudu merupakan suatu pengujian untuk mengetahui kemampuan ekstrak dalam meningkatkan imunoglobulin $\mathrm{M}$ (IgM) dengan cara melihat aglutinasi darah tikus putih terhadap tingkat pengenceran serum darah yang kemudian dihitung angka titer yang bertujuan ekstrak buah mengkudu mampu meningkatkan imunoglonulin $\mathrm{M}$ (IgM) pada tikus putih dan dapat memberikan pengaruh yang berbeda terhadap aktivitas imunoglobulin $\mathrm{M}$ ( $\operatorname{IgM})$ terhadap variasi dosis ekstrak buah mengkudu (EBM). Dari hasil penelitian dengan melihat titer antibodi tikus putih dapat disimpulkan bahwa variasi dosis ekstrak buah mengkudu (EBM) dapat meningkatkan Aktivitas Imunoglobulin M (IgM) pada tikus putih.

Berdasarkan uji pendahuluan maka didapat dosis untuk pengujian. Pengujian dilakukan dengan membagi 15 ekor tikus 
Aktivitas imunoglobulin m (igm) ekstrak buah mengkudu (Morinda citrifolia l.) terhadap tikus putih (rattus norvegiens)

putih menjadi 5 kelompok. Masing-masing kelompok terdiri atas 3 ekor tikus putih. Kelompok pertama sebagai kontrol negatif, kelompok kedua sampai keempat sebagai kelompok uji dimana dosis yang digunakan adalah $\quad 100 \mathrm{mg} / 200 \mathrm{gBB}, \quad 200 \mathrm{mg} / 200 \mathrm{gBB}$ dan $300 \mathrm{mg} / 200 \mathrm{gBB}$, serta kelompok kelima terdiri atas stimuno $0,9 \mathrm{mg} / 200 \mathrm{gBB}$ sebagai kontrol positif.

Tabel 1. Hasil Hemaglutinasi dan Perhitungan Angka Titer

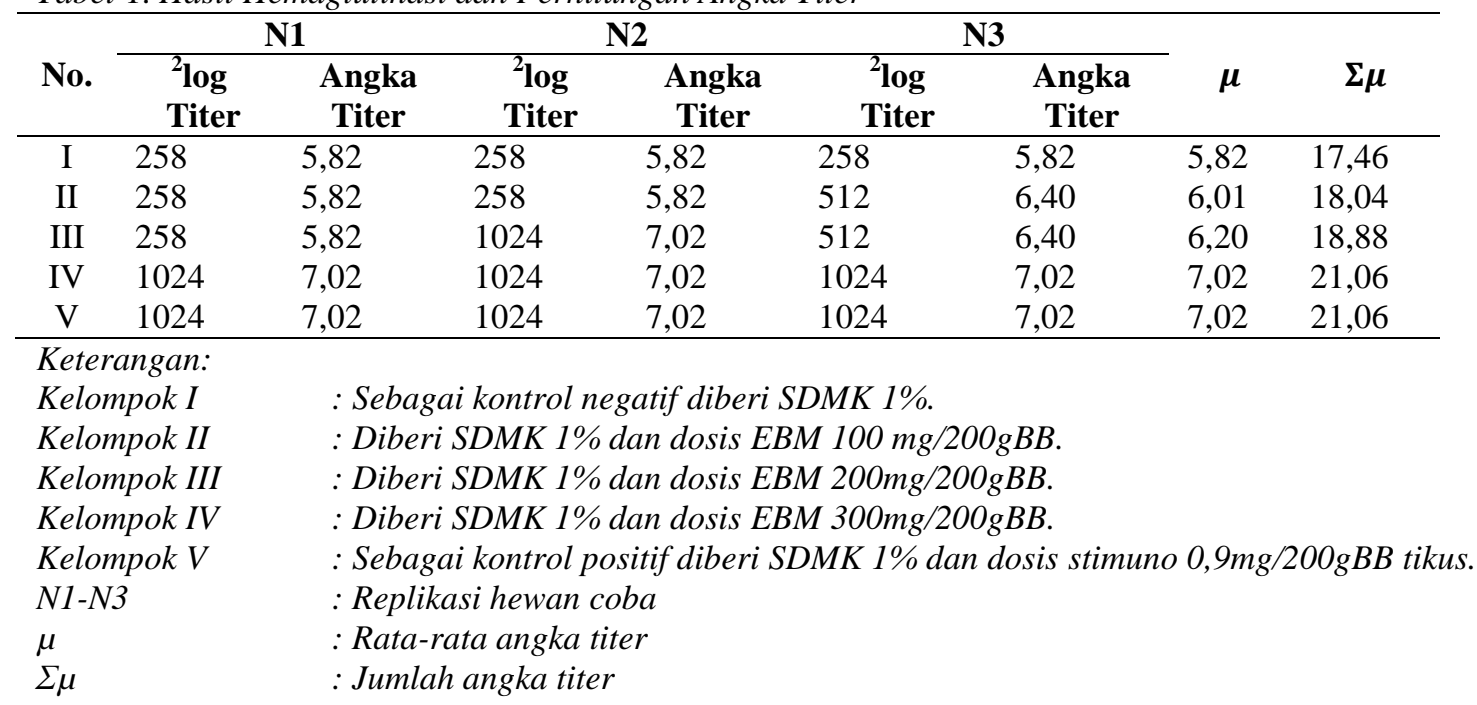

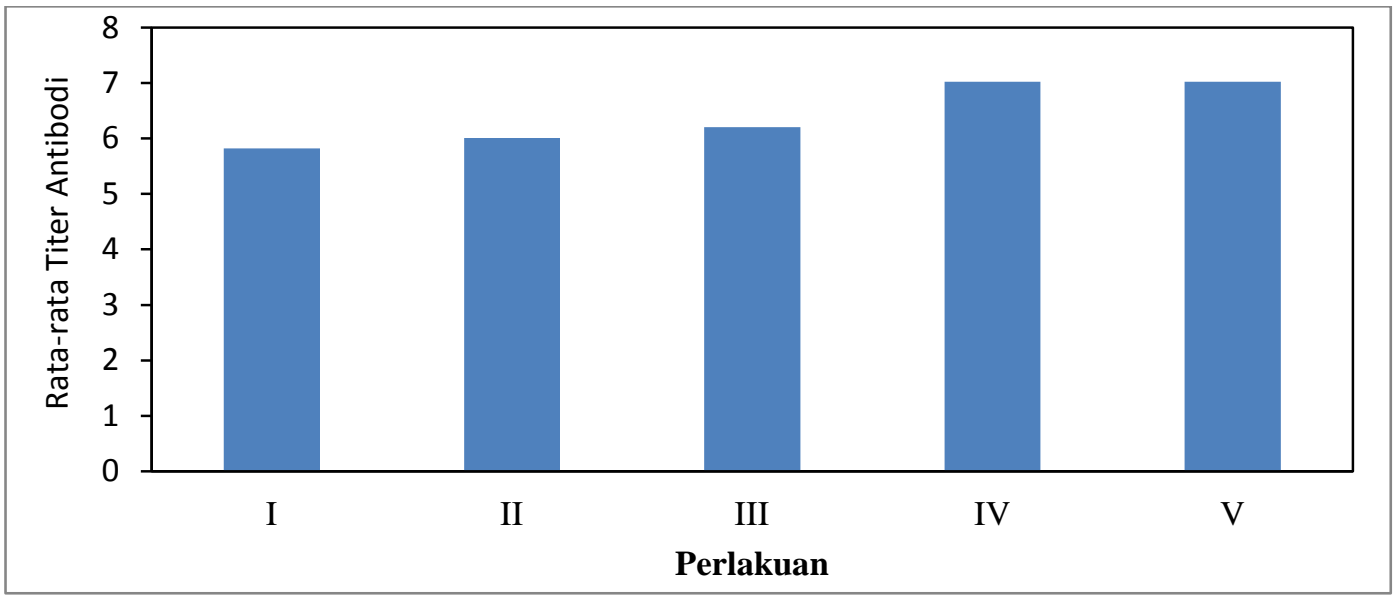

Keterangan:

Kelompok I

Kelompok II

Kelompok III

Gambar 1. Rata-rata Titer Antibodi Tikus Putih

Kelompok IV

Kelompok $V$

: Sebagai kontrol negatif diberi SDMK $1 \%$.

: Diberi SDMK 1\% dan dosis EBM $100 \mathrm{mg} / 200 \mathrm{gBB}$.

: Diberi SDMK 1\% dan dosis EBM 200mg/200gBB.

: Diberi SDMK $1 \%$ dan dosis EBM 300mg/200gBB.

: Sebagai kontrol positif diberi SDMK 1\% dan dosis stimuno 0,9mg/200gBB tikus. 
Aktivitas imunoglobulin m (igm) ekstrak buah mengkudu (Morinda citrifolia l.) terhadap tikus putih (rattus norvegiens)

Tabel 2. Data Anava Pengaruh Ekstrak Buah Mengkudu

\begin{tabular}{ccccccc}
\hline $\begin{array}{c}\text { Sumber } \\
\text { Keragaman }\end{array}$ & Db & JK & KT & F hitung & \multicolumn{2}{c}{ F tabel } \\
\cline { 5 - 7 } & & & & & $\mathbf{5 \%}$ & $\mathbf{1 \%}$ \\
\hline Perlakuan & 2 & 1,54 & 0,77 & & & \\
Galat & 6 & 0,94 & 0,16 & 4,81 & 5,14 & 10,92 \\
Total & 8 & 2,48 & - & & & \\
\hline
\end{tabular}

\section{b. Aktivitas Hemaglutinasi}

Pengujian ini menggunakan metode hemaglutinasi. Hemaglutinasi adalah ikatan yang terjadi antara sel darah merah kambing 1\% (SDMK1\%) sebagai antigen dengan antibodi sehingga menimbulkan aglutinasi atau penggumpalan yang dapat dlihat. Hemaglutinasi terbentuk karena adanya ikatan silang antara sel darah merah dan antibodi. Antibodi yang berikatan dengan SDMK 1\% adalah imunoglobulin M (IgM). Penentuan hemaglutinasi titer antibodi bertujuan untuk menetapkan respon humoral melawan SDMK 1\% yang dibuktikan dengan peningkatan titer antibodi tikus putih. Hasil hemaglutinasi dapat dilihat secara visual. Data hasil penelitian hemaglutinasi dapat dilihat pada Tabel 1.

Berdasarkan Tabel 1 dapat diketahui bahwa adanya peningkatan aktivitas imunoglobulin M (IgM) tikus putih yang diberikan ekstrak buah mengkudu yang ditandai dengan besarnya angka titer. Semakin besar angka titer yang diperoleh maka semakin baik dalam peningkatan aktivitas imunoglobulin $\mathrm{M}$ (IgM) tikus putih. Berikut adalah grafik rata-rata titer antibodi tikus putih yang dapat dilihat pada Gambar 1.

Berdasarkan Gambar 1 menunjukan adanya perbedaan peningkatan aktivitas imunoglobulin $\mathrm{M}$ (IgM) antara dosis ekstrak buah mengkudu (EBM) dengan kontrol negatif, dimana terjadi peningkatan aktivitas imunoglobulin M (IgM) tikus putih setelah diberikan ekstrak buah mengkudu dibandingkan kontrol negatif. Hal ini menunjukan bahwa ekstrak buah mengkudu dapat meningkatkan aktivitas imunoglobulin M (IgM) tikus putih.

\section{c. Dosis Terbaik Ekstrak Buah Mengkudu (EBM)}

Hasil untuk mengetahui adanya perbedaan dari setiap perlakuan pada kelompok dosis pemberian ekstrak hewan coba, dilakukan analisis varians (ANAVA) yang hasil perhitungannya dapat dilihat pada Tabel 2.

Berdasarkan hasil uji anava diperoleh $\mathrm{F}$ hitung < F tabel pada taraf $1 \%$ dan 5\% dimana nilai $\mathrm{F}$ hitung 4,81 . Hal ini berarti bahwa ekstrak etanol buah mengkudu dengan variasi dosis $100 \mathrm{mg} / 200 \mathrm{gBB}, \quad 200 \mathrm{mg} / 200 \mathrm{gBB}$, dan $300 \mathrm{mg} / 200 \mathrm{gBB}$ tidak signifikan atau tidak ada perbedaan variasi dosis terhadap aktivitas untuk meningkatkan imunoglobulin $\mathrm{M}$ (IgM) pada tikus putih pada taraf $1 \%$ ataupun $5 \%$, sehingga tidak dilakukan uji lanjutan melainkan dilakukan uji untuk menentukan dosis terbaik. Dosis terbaik adalah dosis yang mampu memberikan aktivitas dalam meningkatkan imunoglobulin $\mathrm{M}$ (IgM) tikus putih secara maksimal. Dosis terbaik ditentukan dengan membandingkan antar dosis ekstrak buah mengkudu dengan uji-t. Hasil uji-t untuk menentukan dosis terbaik dapat dilihat pada Tabel 3. 
Aktivitas imunoglobulin m (igm) ekstrak buah mengkudu (Morinda citrifolia l.) terhadap tikus putih (rattus norvegiens)

Tabel 3. Data Uji-t Antar Pelakuan Ekstrak Buah Mengkudu

\begin{tabular}{cccc}
\hline Pasangan Subjek & \multirow{2}{*}{ t-Hitung } & \multicolumn{2}{c}{$\mathrm{t}$-Tabel } \\
\cline { 3 - 4 } 300mg/200gBB dan 100mg/200gBB & 6,73 & & \\
300mg/200gBB dan 200mg/200gBB & 2,87 & & \\
200mg/200gBB dan 100mg/200gBB & 1,53 & 2,776 & 4,602 \\
100mg/200gBB dan kontrol negatif & 1,26 & & \\
200mg/200gBB dan kontrol negatif & 2,80 & & \\
300mg/200gBB dan kontrol negatif & $\infty$ & & \\
\hline
\end{tabular}

Berdasarkan hasil data statistik uji-t yang dapat dilihat pada Tabel 3 menunjukan bahwa dosis $300 \mathrm{mg} / 200 \mathrm{gBB}$ terhadap $100 \mathrm{mg} / 200 \mathrm{gBB} \quad$ memiliki aktivitas yang berbeda dalam meningkatkan aktivitas imunoglobulin $\mathrm{M}$ (IgM) tikus putih dan untuk dosis $300 \mathrm{mg} / 200 \mathrm{gBB}$ terhadap $200 \mathrm{mg} / 200 \mathrm{gBB}$ memiliki aktivitas yang berbeda dalam meningkatkan aktivitas imunoglobulin $\mathrm{M}$ (IgM) pada taraf 0,05 dan memiliki aktifitas yang sama dalam meningkatkan aktivitas imunoglobulin M (IgM) pada taraf 0,01 terhadap tikus putih, dan untuk dosis $\quad 200 \mathrm{mg} / 200 \mathrm{gBB}$ terhadap $100 \mathrm{mg} / 200 \mathrm{gBB}$ menunjukan aktivitas yang sama dalam meningkatkan aktivitas imunoglobulin M (IgM) terhadap tikus putih. Sedangkan untuk hasil uji-t dosis $100 \mathrm{mg} / 200 \mathrm{gBB}$ terhadap kontrol negatif menunjukan hasil yang sama dalam meningkatkan aktivitas imunoglobulin $\mathrm{M}$ (IgM) terhadap tikus putih dan untuk hasil uji-t dosis $200 \mathrm{mg} / 200 \mathrm{gBB}$ terhadap kontrol negatif memiliki aktivitas yang berbeda dalam meningkatkan aktivitas imunoglobulin M (IgM) pada taraf 0,05 dan memiliki aktifitas yang sama dalam meningkatkan aktivitas imunoglobulin $\mathrm{M}$ (IgM) pada taraf 0,01 terhadap tikus putih.
Pada dosis 300mg/200gBB terhadap negatif kontrol negatif memiliki aktivitas yang berbeda dalam meningkatkan imunoglobulin M (IgM) tikus putih. Hasil ini dapat disimpulkan bahwa dosis terbaik yang mampu meningkatkan aktifitas imunoglobulin $\mathrm{M}(\mathrm{IgM})$ tikus putih adalah $300 \mathrm{mg} / 200 \mathrm{gBB}$ tikus putih.

\section{KESIMPULAN}

Ekstrak buah mengkudu mampu meningkatkan aktivitas imunoglobulin $\mathrm{M}$ (IgM) dan dosis terbaik ekstrak buah mengkudu yang mampu meningkatkan aktivitas imunoglobulin $\mathrm{M}$ ( $\mathrm{IgM})$ adalah $300 \mathrm{mg} / 200 \mathrm{gBB}$.

\section{DAFTAR PUSTAKA}

[1]. Radji, M. dan Biomed, M. 2010. Imunologi dan Virologi. PT. ISFI Penerbitan. Jakarta.

[2]. Subowo. 2009. Imunobiologi. Edisi 2. Sagung Seto. Jakarta.

[3]. Suhirman,S. dan Winarti, C. 2009. Prospek dan Fungsi Tanaman Obat Sebagai Imunomodulator. Balai Penelitian Tanaman Obat dan Aromatik., Balai Besar Penelitian dan Pengembangan Pascapanen Pertanian. Bogor.

[4]. Tan, H.J. dan Kirana. R. 2003. Obat-Obat Penting, Khasiat, Penggunaan, dan Efek-Efek Sampingnya. Edisi Kelima. Elex Media Computindo Kelompok Gramedia. Jakarta. 